\title{
The international politics of the Middle East
}

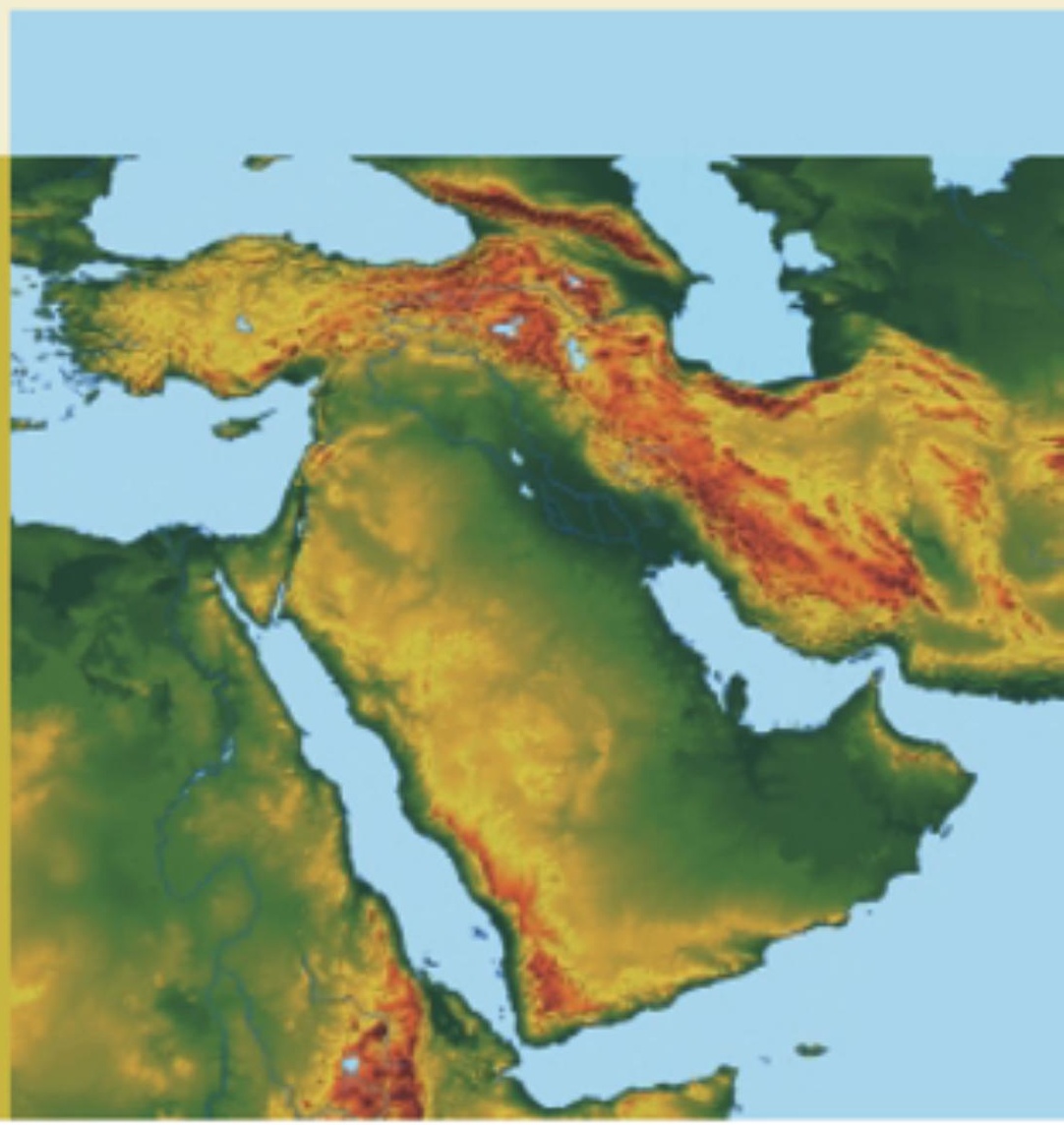

Raymond Hinnebusch 
The international politics of the Middle East

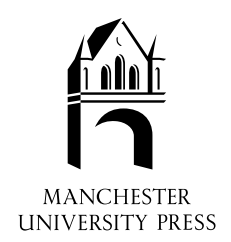




\section{Regional International Politics series}

Already published in the series:

Anderson: $\quad$ The international politics of Central Asia

Calvert: $\quad$ The international politics of Latin America

Hewitt: $\quad$ The new international politics of South Asia

Hyde-Price: The international politics of East Central Europe

Pinkney: $\quad$ The international politics of East Africa

Webber: The international politics of Russia and the successor states 


\section{The international politics of the Middle East}

Raymond Hinnebusch

Manchester University Press

Manchester and New York

distributed exclusively in the USA by Palgrave 
Copyright (C) Raymond Hinnebusch 2003

The right of Raymond Hinnebusch to be identified as the author of this work has been asserted by him in accordance with the Copyright, Designs and Patents Act 1988.

Published by Manchester University Press Oxford Road, Manchester M13 9NR, UK and Room 400, 175 Fifth Avenue, New York, NY 10010, USA www.manchesteruniversitypress.co.uk

Distributed exclusively in the USA by Palgrave, 175 Fifth Avenue, New York, NY 10010, USA

Distributed exclusively in Canada by UBC Press, University of British Columbia, 2029 West Mall, Vancouver, BC, Canada V6T 1Z2

British Library Cataloguing-in-Publication Data

A catalogue record for this book is available from the British Library

Library of Congress Cataloging-in-Publication Data applied for

ISBN 0719053455 hardback

0719053463 paperback

First published 2003

$\begin{array}{lllllllll}11 & 10 & 09 & 08 & 07 & 06 & 05 & 04 & 03\end{array}$

$\begin{array}{llllllllll}10 & 9 & 8 & 7 & 6 & 5 & 4 & 3 & 2 & 1\end{array}$

Typeset in Sabon

by Servis Filmsetting Ltd, Manchester

Printed in Great Britain

by Bell \& Bain Ltd, Glasgow 